\title{
A New Method for the Determination of 1:2-Dithiols
}

\author{
By W. N. ALDRIDGE, Ministry of Supply, Chemical Defence Experimental Station, Porton
}

(Received 6 January 1947)

The use of 1:2-dimercaptopropanol (BAL) for the treatment of systemic arsenic intoxication after massive contamination with arsenical vesicants, and after overdosage with arsenicals during arsenotherapy, makes essential a method of high sensitivity for its determination, especially in biological materials. The only method at present available (Spray, 1944) depends on the colour produced by the addition of cobalt salts to solutions of BAL. This method is rather insensitive and the metallic complex, being insoluble, has to be maintained in solution by the use of a protective colloid, a procedure which gives uncertain results. It is also by no means specific, for cobalt salts give colours with almost all thio compounds (Spray, Stocken \& Thompson, 1945). The procedure adopted by Spray (1944) for determination in blood involved ultrafiltration after acidification to stabilize the BAL; by this means $80-85 \%$ of BAL was recovered from plasma and some $40-60 \%$ from blood. In our opinion any method which depends on the isolation of BAL as such from blood is likely to have little success, it being too unstable in this medium.

\section{EXPERIMENTAL \\ Principles of method}

It has been found that 1:2-dithiols react with cyanogen chloride to produce an unidentified compound which readily liberates thiocyanate in alkaline solution. The determination of thiocyanate in micro-quantities has been previously reported (Aldridge, 1944, 1945).

For its determination in biological materials, we have not attempted the isolation of BAL but have converted it to the much more stable compound of BAL with cyanogen chloride and then recovered this compound by a protein precipitation technique (Folin, 1930).

\section{Reagents}

Cyanogen chloride solution. (a) For determination of BAL in aqueous solution carefully pipette $0.1 \mathrm{ml}$. (approx.) cyanogen chloride, using an ice-cold pipette, into $200 \mathrm{ml}$. of $\mathrm{Na}$ acetate (c. $1 \mathrm{~N})$. (b) For determination of BAL in blood and urine, $0.1 \mathrm{ml}$. cyanogen chloride in $100 \mathrm{ml} .3 \cdot 8 \%(\mathrm{w} / \mathrm{v})$ $\mathrm{Na}_{2} \mathrm{SO}_{4} \cdot 10 \mathrm{H}_{2} \mathrm{O}$. Great care should be exercised in the handling of cyanogen chloride. It is highly toxic and extremely volatile (b.p. $14^{\circ}$ ) and should be stored in a refrigerator in a bottle with a well greased stopper having an external joint.

Bromine water. (a) For determination of BAL in aqueous solution, a half-saturated solution. (b) For determination of BAL in blood and urine, saturated solution.

Arsenious acid. $2 \%(\mathrm{w} / \mathrm{v})$ solution. To obtain complete solution boil under reflux.

$\mathrm{N}$-Sodium acetate. $13 \cdot 6 \%(\mathrm{w} / \mathrm{v})$ solution of sodium acetate, $\mathrm{CH}_{3}$. $\mathrm{COONa} .2 \mathrm{H}_{2} \mathrm{O}$.

Sodium tungstate. $10 \%(\mathrm{w} / \mathrm{v})$ solution $\mathrm{Na}_{2} \mathrm{WO}_{4} \cdot 2 \mathrm{H}_{2} \mathrm{O}$ neutralized to phenolphthalein.

Pyridine reagent. To 11 . of the constant boiling mixture of pyridine and water ( $59 \%$ pyridine), add $100 \mathrm{ml}$. of conc. HCl.

Benzidine reagent. $5 \%(\mathrm{w} / \mathrm{v})$ solution of recrystallized benzidine hydrochloride in $2 \%(\mathrm{v} / \mathrm{v}) \mathrm{HCl}$.

$A$ :ids, etc. $\mathrm{N}-\mathrm{NaOH}, 3 \mathrm{~N}-\mathrm{HCl}, 0.66 \mathrm{~N}-\mathrm{H}_{2} \mathrm{SO}_{4}$.

\section{Reaction of dithiols with cyanogen chloride}

The reaction of cyanogen chloride with 1:2-dithiols in aqueous solution has been studied at $\mathrm{pH}$ values of 6-10. To $6 \mathrm{ml}$. 0.05 M-phosphate buffer at the required $\mathrm{pH}$ (checked by glass electrode) were added $2 \mathrm{ml}$. cyanogen chloride solution (1 mg.) and $2 \mathrm{ml}$. BAL solution (70 $\mu \mathrm{g}$.). At various times, $1 \mathrm{ml}$. of the above solution was pipetted into $1.8 \mathrm{ml}$. $0.2 \mathrm{~N}-\mathrm{NaOH}$. After leaving for $10 \mathrm{~min}$., the solution was rendered acid by the addition of $0.2 \mathrm{ml}$. $3 \mathrm{~N}-$ $\mathrm{HCl}$. The thiocyanate formed was estimated in the usual way (Aldridge, 1944, 1945). It is seen from Table 1 that

Table 1. Speed of reaction of cyanogen chloride with 1:2-dithiols at various acidities

(Thiocyanate determined at various times.)

\begin{tabular}{cccc} 
Time & \multicolumn{3}{c}{ Spekker readings } \\
\cline { 2 - 4 } (min.) & $\overbrace{\mathrm{pH} 6.0}$ & $\mathrm{pH} \mathrm{7.0}$ & $\mathrm{pH} \mathrm{8.0}$ \\
0.5 & 0.36 & 0.50 & 0.495 \\
1 & 0.41 & 0.51 & 0.505 \\
2 & 0.44 & 0.54 & 0.54 \\
4 & 0.465 & 0.54 & 0.54 \\
8 & 0.52 & 0.54 & 0.54 \\
16 & 0.535 & - & -
\end{tabular}

the reaction is complete in 2 min. at $\mathrm{pH} \mathrm{7-8}$ while at $\mathrm{pH} 6$ it requires $15 \mathrm{~min}$. As a convenient aoidity for the reaction, pH 7 has been chosen, though any high pH may be used provided sufficient excess of cyanogen chloride is added in order that the reaction between BAL and cyanogen chloride is complete before all the cyanogen chloride is hydrolyzed. The poor stability of BAL at high $\mathrm{pH}$ prevents the use of very alkaline solutions. 
Cyanogen chloride may be determined in aqueous solution by omitting the bromination stage in the normal thiocyanate method. By a determination of the residual cyanogen chloride after reaction with $\mathrm{BAL}$ at various $\mathrm{pH}$, it has been possible to determine the molecular proportions of cyanogen chloride and BAL taking part in the reaction. Within the limits of experimental error, 1 mol. of cyanogen chloride reacts with $1 \mathrm{~mol}$. of dithiol (Table 2).

\section{Table 2. Determination of molecular proportions of} cyanogen chloride and $B A L$ in reaction

(34 $\mu \mathrm{g}$. BAL taken and excess cyanogen chloride determined after completion of reaction at various $\mathrm{pH}$. Blank contains all reagents except dithiol.)

\begin{tabular}{|c|c|c|c|c|}
\hline \multirow[b]{2}{*}{$\mathrm{pH}$} & \multicolumn{2}{|c|}{ Spekker reading } & \multirow{2}{*}{$\begin{array}{c}\text { Cyanogen } \\
\text { chloride } \\
\text { reacting } \\
(\mu \mathrm{g} .)\end{array}$} & \multirow{2}{*}{$\begin{array}{c}\text { Mol. } \\
\text { cyanogen } \\
\text { chloride } \\
\text { /mol. BAI }\end{array}$} \\
\hline & Blank & Dithiol & & \\
\hline $6 \cdot 32$ & $1 \cdot 04$ & $0 \cdot 26$ & $15 \cdot 9$ & 0.93 \\
\hline $6 \cdot 9$ & 1.04 & $0 \cdot 25$ & $16 \cdot 1$ & 0.94 \\
\hline $7 \cdot 96$ & 1.03 & 0.20 & $16 \cdot 9$ & 0.99 \\
\hline 9.95 & 0.92 & $0 \cdot 15$ & $15 \cdot 7$ & 0.92 \\
\hline
\end{tabular}

As will be shown later, 1:3-dimercaptopropanol does not interfere in the estimation but acts as a reducing agent and cyanogen chloride is converted to cyanide and chloride. The cyanogen chloride which reacts with 1:3-dithiol is determined as given previously, and cyanogen chloride together with HCN is estimated by including the bromination process as for thiocyanate estimation. The results (Table 3) show that all the reacting cyanogen chloride is reduced to cyanide. Examination of BAL in an identical manner indicates that of the $1 \mathrm{~mol}$. of cyanogen chloride reacting with $1 \mathrm{~mol}$. BAL, $0.05 \mathrm{~mol}$. cyanide is produced (Table 3).

Estimation of SH groups present during the reaction by titration in acid solution with iodine shows that after the

\section{Alkaline treatment of the compound of $B A L$ with cyanogen chloride}

The reaction product between cyanogen chloride and 1:2-dithiols, although stable in acid solution, liberates thiocyanate completely 5 min. after making alkaline with $\mathrm{NaOH}$. Thiocyanate is also liberated, though more slowly, at $\mathrm{pH}$ values 9-10 (Table 5).

The excess cyanogen chloride left in solution is also destroyed by treatment with alkali, being in the main converted to sodium cyanate. However, a small percentage is converted to cyanide (Aldridge, 1945) which would of course react in the same manner as thiocyanate in the subsequent determination. The cyanide is readily removed by making the solution acid after alkaline treatment for $10 \mathrm{~min}$. and bubbling air through the solution for $30 \mathrm{~min}$. (air saturated with water vapour is used to prevent evaporation of the solution). This has no effect on the thiocyanate (Aldridge, 1944). With a blank determination, adding all the reagents except the dithiol, a zero reading on the Spekker absorptiometer is obtained with Ilford spectrum green 604 filters.

It has been shown that a small proportion of cyanide is liberated together with thiocyanate during the alkaline treatment. To determine the amount of cyanide, solutions of the BAL-cyanogen chloride compound were rendered acid and aerated to remove excess cyanogen chloride. Thiocyanate and cyanide were then estimated by the normal procedure and thiocyanate alone after removal of the cyanide by further aeration. Table 6 shows that while about $0.8 \mathrm{~mol}$. thiocyanate are liberated from $1 \mathrm{~mol}$. BAL, $0.05 \mathrm{~mol}$. cyanide is also produced.

It should be noted that after the reaction of 1:2-dithiols with cyanogen chloride there are two possible procedures: (a) render the solution acid and aerate to remove excess cyanogen chloride, before liberating the thiocyanate, or (b) remove cyanide produced during destruction of excess

\section{Table 3. Reaction of 1:3-dimercaptopropanol and BAL with cyanogen chloride at $\mathrm{pH} 7$}

(Cyanogen chloride and cyanogen chloride $+\mathrm{HCN}$ determined after completion of reaction. Blank contains all reagents except dithiol.)

Estimation
$\mathrm{CNCl}$
$\mathrm{CNCl}+\mathrm{HCN}$
$\mathrm{HCN}$ (by diff.)

$\mathrm{CNCl}$
$\mathrm{CNCl}+\mathrm{HCN}$
$\mathrm{HCN}$ (by diff.)

Spekke
Blank
0.625
0.630
0.005

$$
\text { adings }
$$

Dithiol

1:3-Dimercaptopropanol

$0.030 \quad \mathrm{CNCl}$ reacting, $6.98 \mathrm{~mol} . / \mathrm{mol}$. dithiol

$0 \cdot 630$

0.600 HCN produced, $0 . \overline{98} \mathrm{~mol} . / \mathrm{mol}$. dithiol

\section{1:2-Dimercaptopropanol (BAL)}

$\begin{array}{lll}0.980 & 0.290 & \mathrm{CNCl} \text { reacting, } 1.01 \mathrm{~mol} . / \mathrm{mol} \text {. dithiol } \\ 1.010 & 0.355 & \\ 0.030 & 0.065 & \mathrm{HCN} \text { produced, } 0.052 \mathrm{~mol} . / \mathrm{mol} \text {. dithiol }\end{array}$

initial reaction with cyanogen chloride both SH groups are substituted, and that after alkaline treatment to liberate thiocyanate from the compound of BAL with cyanogen chloride, some indication of the reappeatance of $\mathrm{SH}$ groups is shown (Table 4). The fact that $\mathrm{SH}$ groups are present after treatment with $\mathrm{NaOH}$, in which medium dithiols are rapidly oxidized to the disulphide form, is a strong indication that a greater proportion was produced than that titrated.

\section{Table 4. Determination of $S H$ groups during $B A L$-cyanogen chloride reaction}

(SH groups titrated with $0.01 \mathrm{~N}-\mathrm{I}_{2}$ in acid solution.) Initial

Time of estimation

After reaction with $\mathrm{CNCl}$

After alkaline treatment 
Table 5. Liberation of thiocyanate from BAL-cyanogen chloride compound at various acidities at room temperature

$\begin{array}{ccc}\overbrace{\text { Time }} & \text { Caustic alkali } \\ \text { (min.) } & \begin{array}{c}\text { Spekker } \\ \text { reading }\end{array} & \begin{array}{c}\text { \% of } \\ \text { total }\end{array} \\ 1 & 0.390 & 93 \\ 2 & 0.400 & 95 \\ 4 & 0.405 & 96 \\ 10 & 0.410 & 98 \\ 16 & 0.410 & 98 \\ 24 \mathrm{hr} . & 0.420 & 100\end{array}$

$\begin{array}{ccc}\begin{array}{c}\text { Time } \\ \text { (min.) }\end{array} & \begin{array}{c}\text { Spekker } \\ \text { reading }\end{array} & \begin{array}{c}\text { \% of } \\ \text { total }\end{array} \\ 3 & 0.037 & 8.5 \\ 6 & 0.052 & 12 \\ 12 & 0.065 & 15 \\ 24 & 0.080 & 18.5 \\ 48 & 0.112 & 26\end{array}$

\begin{tabular}{ccl}
\multicolumn{3}{c}{ pH 10.0 } \\
$\begin{array}{c}\text { Time } \\
\text { (min.) }\end{array}$ & $\begin{array}{c}\text { Spekker } \\
\text { reading }\end{array}$ & $\begin{array}{l}\text { \% of } \\
\text { total }\end{array}$ \\
3 & 0.110 & 25 \\
6 & 0.130 & 29.5 \\
12 & 0.185 & 42 \\
24 & 0.255 & 58 \\
48 & 0.315 & 72
\end{tabular}

Table 6. Alkaline treatment of BAL-cyanogen chloride compound

(Excess cyanogen chloride removed by aeration in acid solution followed by alkaline treatment. Thiocyanate + cyanide and thiocyanate estimated.)

$$
\begin{aligned}
& \text { Estimation } \\
& \text { HCNS + HCN } \\
& \text { HCNS } \\
& \text { HCN (by diff.) }
\end{aligned}
$$

\begin{tabular}{|c|c|}
\hline \multicolumn{2}{|c|}{ Spekker readings } \\
\hline Blank & Dithiol \\
\hline $\begin{array}{l}0.052 \\
0.020\end{array}$ & $\begin{array}{l}0.790 \\
0.720\end{array}$ \\
\hline 0.030 & 0.070 \\
\hline
\end{tabular}

cyanogen chloride with alkali as given in the description of the method. Procedure $(a)$ is useful in the elimination of interference of ergothioneine and gives slightly higher results than $(b)$ owing to the extra $0.05 \mathrm{~mol}$. cyanide $/ \mathrm{mol}$. BAL (Table 6). Procedure (b) has been adopted because the removal of the relatively large quantity of cyanogen chloride by $(a)$ requires rather long aeration.

\section{Specificity of the reaction}

In order to check the specificity of the reaction for 1:2dithiols, a large number of compounds has been examined for interference and especially those likely to be encountered in biological fluids. The following is a list of those tested:

$\begin{array}{ll}\text { 1:3-Dimercaptopropanol } & \text { Methionine } \\ \text { Hexane-1:6-dithiol } & \text { Ethyl sulphide } \\ \text { Monothioethylene glycol } & n \text {-Butyl sulphide } \\ \text { BAL in disulphide form } & \text { Thiophenol } \\ \text { Cysteine hydrochloride } & \text { Ethyl mercaptan } \\ \text { Cystine } & \text { Ergothioneine } \\ \text { Thiodiglycol } & \text { Glutathione } \\ \text { Thioglycollic acid } & \text { Thiolacetic acid }\end{array}$

The general method we have adopted for the examination of such compounds has been to treat 50 and $30 \mu \mathrm{g}$. of the compounds (c. $10 \mu \mathrm{g}$. of BAL gives a Spekker reading of 1.0) as for the estimation of 1:2-dithiols. In addition, a blank was run with $50 \mu \mathrm{g}$. of the compound and all the reagents except cyanogen chloride; this checks for the presence of thiocyanate and any other similar interfering substances. With the above procedure, all except three of the compounds listed in the text gave zero readings: glutathione, ergothioneine and thiolacetic acid. It is not at all clear why glutathione reacts; $40 \mu$ g. gives a Spekker reading of 0.09 (c. $1 \mu \mathrm{g}$. of $\mathrm{BAL}$ gives the same reading). It is possible that this result is due to some impurity in the sample of glutathione examined. Ergothioneine reacts slowly with cyanogen chloride at high $\mathrm{pH}$ values and to a small extent up to acidities of pH 9 (Table 7). Interference of ergothioneine in the method must therefore take place when $\mathrm{NaOH}$ is added to liberate thiocyanate and to
HCNS produced, $\overline{0.79} \mathrm{~mol} . / \mathrm{mol}$. BAL HCN produced, $0.05 \mathrm{~mol} . / \mathrm{mol}$. BAL

Table 7. Speed of reaction of cyanogen chloride with ergothioneine at various acidities

(Cyanogen chloride allowed to react with ergothioneine for 20 min. Estimation as for that of BAL.)

$\begin{array}{cc}\text { pH } & \text { Spekker reading } \\ 7 \cdot 2 & 0.02 \\ 8.06 & 0.02 \\ 9 \cdot 0 & 0.04 \\ 10.0 & 0.150\end{array}$

destroy excess cyanogen chloride. If necessary, interference from ergothioneine may be prevented by removing excess cyanogen chloride by a stream of air before making alkaline as mentioned previously. However since ergothioneine is not recovered from blood with the protein precipitation procedure to be described, the need for this alteration in the technique is not common. In amounts of $12 \mu \mathrm{g}$., thiolacetic acid gives a Spekker reading of 0.45 (Table 8). This is about $25 \%$ of the theoretical value expected if $1 \mathrm{~mol}$. of thiocyanate should be obtained from each mol. thiolacetic acid. It is probable that, in the highly alkaline solution, sulphide is produced which reacts with the excess cyanogen chloride or the small amount of cyanide liberated during the hydrolysis of cyanogen chloride.

\section{Table 8. Interference of thiolacetic acid in the method}

(Various amounts of thiolacetic acid treated as for BAL estimation. Recoveries are based on the theoretical liberation of $1 \mathrm{~mol}$. HCNS/mol. thiolacetic acid.)

Thiolacetic acid
$(\mu \mathrm{gg})$
$6 \cdot 05$
$12 \cdot 1$
$18 \cdot 2$
$24 \cdot 2$
$30 \cdot 3$

Spekker
reading
0.220
$0 \cdot 455$
0.605
0.835
1.03

Recovery 


\section{Procedure for the estimation of 1:2-dithiols}

Description. To $2 \mathrm{ml}$. of a solution containing not more than $10 \mu \mathrm{g}$. of a 1:2-dithiol, add $0.4 \mathrm{ml}$. of the cyanogen chloride reagent, mix and allow to stand for $5 \mathrm{~min}$. Add $0.4 \mathrm{ml}$. $\mathrm{N}-\mathrm{NaOH}$ and allow to stand for $10 \mathrm{~min}$. Make acid by the addition of $0.2 \mathrm{ml}$. $3 \mathrm{~N}-\mathrm{HCl}$ and bubble air saturated with water vapour through the solution for $30 \mathrm{~min}$. Add $0.2 \mathrm{ml}$. bromine water, mix and remove excess bromine with $0.2 \mathrm{ml}$. arsenious acid. Mix well, blow out any bromine vapour left in the tube, and pour into a previously prepared mixture of $4 \mathrm{ml}$. pyridine reagent and $0.8 \mathrm{ml}$. benzidine reagent (total volume of solution $8.2 \mathrm{ml}$.). Mix well by pouring back and forth between the tubes. Allow the colour to develop for $20 \mathrm{~min}$. and then read on the Spekker absorptiometer or any .other photoelectric instrument with $1 \mathrm{~cm}$. cells and Ilford spectrum green 604 filters. It should be noted that throughout this work syringe pipettes (maximum error $0.2 \%$ ) have been used. With the numerous additions of small quantities of reagents great accuracy in measurements is essential. In order to prevent the catalytic oxidation of the dithiols due to the presence of traces of metals in the distilled water, special precautions have been taken in preparing the standard solutions for the determination of the calibration curves. The solvent used was distilled water, saturated with $\mathrm{CO}_{2}$, and to which $10 \mu \mathrm{g}$. $\mathrm{Na}$ cyanide $/ \mathrm{ml}$. were added to poison the metallic catalysts. This procedure seems effectively to prevent the oxidation. The figures obtained for the calibration curves for three dithiols are given in Table 9.

Table 9. Calibration curves for 1:2-dimercaptopropionic acid, 1:2-propane dithiol and $B A L$

(Recoveries are based on the theoretical liberation of $1 \mathrm{~mol}$. thiocyanate $/ \mathrm{mol}$. of dithiol. Photometric readings (Ilford spectral green 604 filters, $1 \mathrm{~cm}$. cells).)

\begin{tabular}{rcc}
$\begin{array}{c}\text { Amount } \\
(\mu \mathrm{g} .)\end{array}$ & $\begin{array}{c}\text { Spekker } \\
\text { reading }\end{array}$ & $\begin{array}{c}\text { Recover } \\
(\%)\end{array}$ \\
\multicolumn{1}{c}{ 1:2-Dimercaptopropionic acid } & \\
$2 \cdot 20$ & $0 \cdot 180$ & 92 \\
$4 \cdot 41$ & $0 \cdot 350$ & 90 \\
$6 \cdot 61$ & $0 \cdot 520$ & 89 \\
$8 \cdot 81$ & $0 \cdot 690$ & 88 \\
$11 \cdot 02$ & $0 \cdot 860$ & 88 \\
& & \\
3.33 & $1: 2$-Propane dithiol & \\
$6 \cdot 66$ & $0 \cdot 305$ & 81 \\
$9 \cdot 99$ & $0 \cdot 610$ & 81 \\
& $0 \cdot 905$ & 80 \\
$1: 2-$ Dimercaptopropanol (BAL) \\
$2 \cdot 31$ & $0 \cdot 175$ & 77 \\
$4 \cdot 62$ & $0 \cdot 550$ & 77 \\
$6 \cdot 93$ & $0 \cdot 540$ & 79 \\
$9 \cdot 24$ & $0 \cdot 720$ & 79 \\
11.56 & 0.905 & 79
\end{tabular}

Application to biological fluids. Pipette as soon as possible $1 \mathrm{ml}$. of whole blood into $1.5 \mathrm{ml}$. cyanogen chloride reagent in isotonic $\mathrm{Na}$ sulphate contained in a centrifuge tube. Leave for $10 \mathrm{~min}$., then add a further $1 \mathrm{ml}$. cyanogen chloride reagent and leave

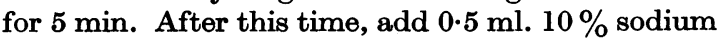
tungstate, mix well and follow by $0.5 \mathrm{ml} .0 .66 \mathrm{~N}$ $\mathrm{H}_{2} \mathrm{SO}_{4}$. Mix again and centrifuge for $10 \mathrm{~min}$. The same procedure is satisfactory for BAL in plasma. It is essential to have the blood in contact with the cyanogen chloride as soon as possible to minimize losses of BAL due to decomposition. The procedure used for urine is as given above for blood except that $1 \mathrm{ml}$. $\mathrm{N}$-sodium acetate is added to the cyanogen chloride reagent before the addition of the urine and no tungstate or sulphuric acid is required. The procedure thenceforward is identical for blood and urine. To not more than $2.0 \mathrm{ml}$. of filtrate from blood protein precipitation or urine solution add $0.4 \mathrm{ml}$. $\mathrm{N}-\mathrm{NaOH}$ and leave for $10 \mathrm{~min}$. Acidify with $0.2 \mathrm{ml}$. $3 \mathrm{~N}-\mathrm{HCl}$, make up to $2.6 \mathrm{ml}$. with water and bubble air saturated with water vapour through the solution for $30 \mathrm{~min}$. to remove cyanide. Brominate with $0.4 \mathrm{ml}$. bromine water, removing excess with $0.4 \mathrm{ml}$. arsenious acid. Mix well, blow out any bromine vapour and continue as given under 'description'. For the thiocyanate blank determination, the above procedure is followed replacing the cyanogen chloride reagent with the same volume of isotonic sodium sulphate solution, i.e. $2.5 \mathrm{ml}$. The difference between the two determinations gives the 1:2-dithiol concentration (plus any interfering substances) and should be referred to the calibration curve as determined before.

\section{DISCUSSION}

\section{Mechanism of reaction}

Of the theoretical yield of thiocyanate based on a reaction of $1 \mathrm{~mol}$. of cyanogen chloride with $1 \mathrm{~mol}$. of BAL, $78 \%$ is obtained (Table 9). Iodine titration of the BAL gave $98.6 \%$ purity. This titration includes substances such as 1:3-dimercaptopropanol but excludes substances such as the oxidized form of BAL. It has been shown that 1 mol. cyanogen chloride reacts with 1 mol. BAL (Table 2) and that $0.8 \mathrm{~mol}$. of thiocyanate is easily liberated in alkaline solution (Table 5); slowly at $\mathrm{pH} 9$ and quickly in $\mathrm{NaOH}$. 1:3-Dimercaptopropanol also reacts with cyanogen chloride but no thiocyanate is liberated in alkaline solution; however, cyanide is liberated equivalent to the cyanogen chloride which has reacted (Table 3). Determination of SH groups during the reaction has shown that both are substituted after the reaction with cyanogen chloride, but after the alkaline treatment they reappear to a small extent $(0.2 \mathrm{SH}$ groups/molecule of BAL (Table 4)). 
Since cyanide is produced equivalent to the amount of cyanogen chloride reacting with 1:3dimercaptopropanol, it would seem that it is a simple reduction of cyanogen chloride to cyanide and chloride, i.e.

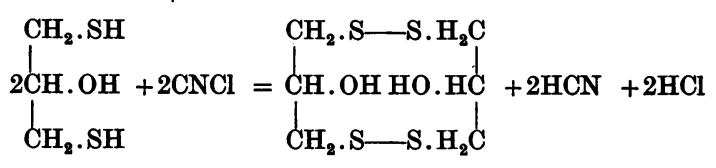

or

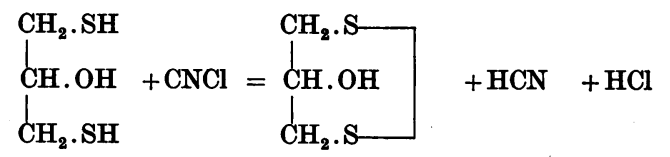

Since $1 \mathrm{~mol}$. of cyanogen chloride reacts with $1 \mathrm{~mol}$. of BAL and both SH groups have been shown to be substituted, it is probable that the initial reaction product has a cyclic structure. Further, since thiocyanate is so easily split off, the compound must be unstable and since some indication of the reappearance of SH groups has been obtained, a reaction of the following type may take place:<smiles>OCC(O)CS</smiles>

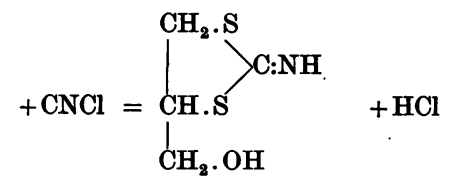<smiles>NC1CC(CO)CS1</smiles><smiles>O=C([18OH])C(O)CO</smiles>

The compound produced is stable in acid solution and bromination in acid solution without liberating thiocyanate produces no cyanogen bromide. There is also the possibility that an organic thiocyanate is formed, from which no cyanide or thiocyanate would be liberated with the mild conditions in the method. A further possibility is that the cyanogen chlorideBAL compound postulated might be hydrolyzed to produce ammonia, i.e.<smiles>NC1SCC(CO)S1</smiles><smiles>O=C1CSC(CO)C1</smiles>
$+\mathrm{NH}_{3}$

The fact that only $0.8 \mathrm{~mol}$. of thiocyanate is obtained from $1 \mathrm{~mol}$. BAL may therefore be attributed to $(a)$ impurity of the sample used for standardization and/or (b) other reactions taking place concurrently. Table 9 shows that from 1:2-dimercaptopropionic acid, $0.9 \mathrm{~mol}$. thiocyanate is obtained $/ \mathrm{mol}$; in view of the fact that this compound is a crystalline solid it is possible that it is the purest of the three dithiols examined. However, whether the variation in recovery of thiocyanate between 1:2-dimercaptopropionic acid and BAL is due to a difference in purity, or to the reaction taking a different course, is a very open question.

\section{Application of the method to biological fluids}

To determine BAL in blood, use has been made of the stability of the BAL-cyanogen chloride compound in acid solution and the fact that it is recoverable from blood after precipitation of protein. In view of the catalytic action of hremoglobin on the oxidation of BAL, cyanogen chloride has been added in isotonic solution and the protein precipitated by the method of Folin (1930). It should be noted that sodium sulphate must be used for the isotonic solution, and not sodium chloride, which acts as a peptizing agent for tungstic acid so that the centrifugates contain protein and colloidal tungstic acid. The addition of cyanogen chloride to blood produces some cyanide but no thiocyanate (Aldridge \& Lovatt Evans, 1946). The cyanide is removed by aeration after protein precipitation. Cyanogen chloride is rapidly taken up by proteins in blood, and an excess must therefore be added to ensure a sufficiency for the BAL-cyanogen chloride reaction to go to completion.

In view of the instability of BAL in blood, indirect methods have been used for the determination of its recovery. Degradation curves have been prepared which have been extrapolated to zero time. (Fig. 1). By this means it has been shown that recoveries of 90-95\% may be expected both from whole blood and plasma. The degradation rate in plasma and serum seems to be higher than that in whole blood. Varying the amount of haemoglobin in the plasma or the addition of citrate and/or cyanide as metallic catalyst poisons had little effect on this rate (Figs. 2, 3). It is possible that this may be due to the incorporation of BAL into an oxidationreduction system, which retards its oxidation in whole blood, while in plasma no such system is present. Thiocyanate blanks should always be carried out, though these are very low in whole blood because thiocyanate is absorbed by whole blood protein precipitates. Determination of 1:2dithiols in normal whole blood has so far yielded negative results.

Much difficulty has been encountered in the determination of BAL in urine. The urine must be buffered to about pH 7 for the cyanogen chloride reaction and more bromine water must be added in order to leave an excess. Our examination of the recovery of BAL from various urines has given $100 \%$ recovery only from rather dilute samples from human males; with these samples the 'dithiol blank' was zero. With other samples, in which the 'dithiol blanks' were high (Fig. 4), the recoveries were very 
low and the degradation curves were an extraordinary shape. On no occasion have we obtained $100 \%$ recovery from female urine. In many cases , we have experienced discolorations of the final colorimetric solution, showing a distinctly brownish shade when compared with those obtained with pure aqueous solutions of BAL.

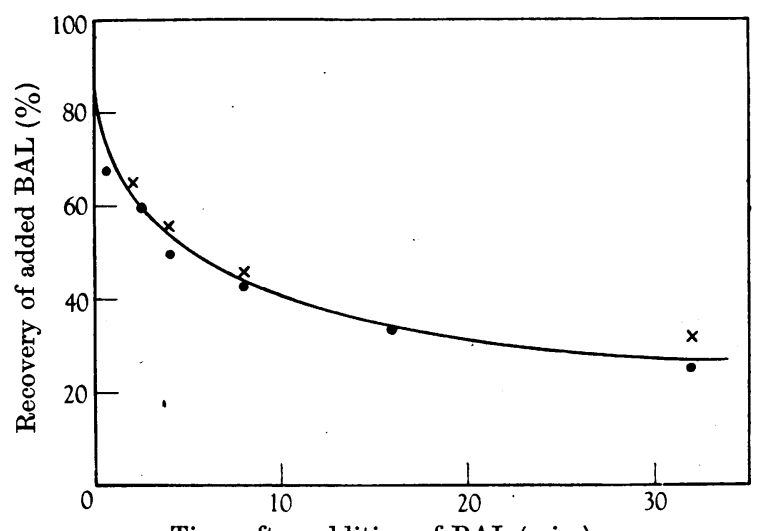

Time after addition of BAL (min.)

Fig. 1 . possible. There are two possible reasons for the low recovery $(a)$ the analytical method is not estimating the substance owing to interference from other substances, or (b) the substance has been converted to some other derivative which is not determined. If (b) is true, the determination of the recovery of consecutive additions of the substance some-

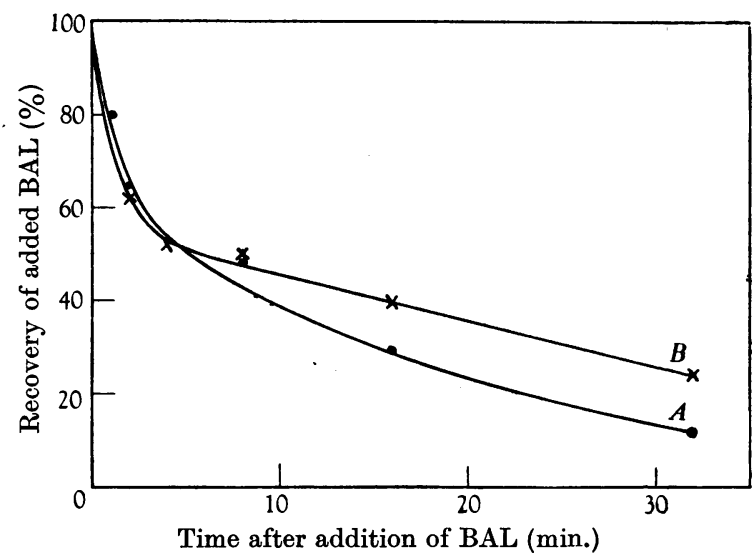

Fig. 2.

Fig. 1. Recovery of added BAL from whole blood. Two determinations plotted.

Fig. 2. Recovery of added BAL from serum. Curve $A$, cat serum (free from haemoglobin); curve $B$, same cat serum with added cyanide.

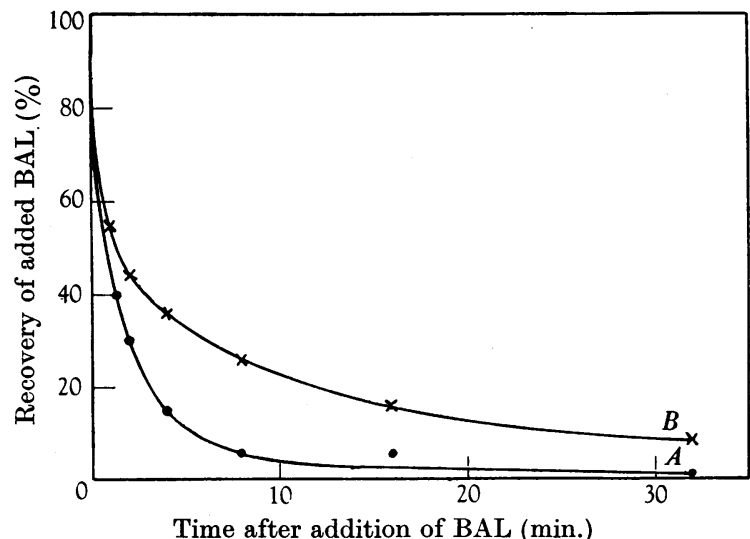

Fig. 3.

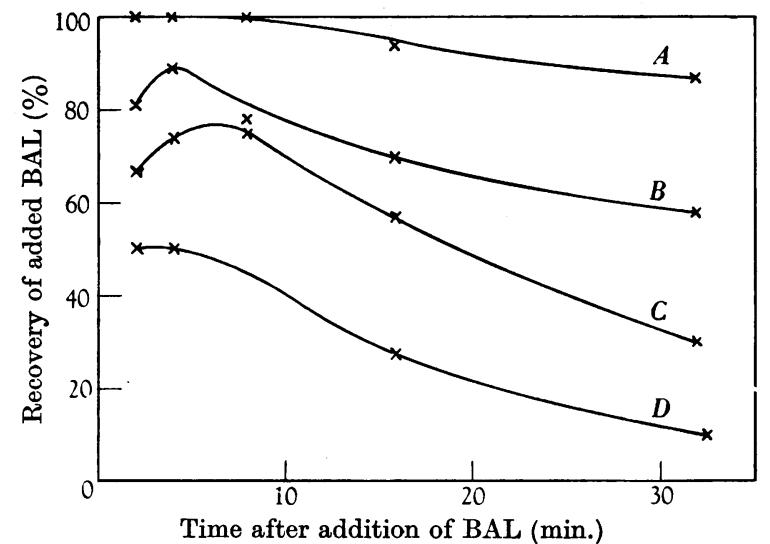

Fig. 4.

Fig. 3. Recovery of added BAL from plasma. Curve $A$, rabbit plasma from defibrinated blood; curve $B$, same rabbit plasma with added citrate.

Fig. 4. Recovery of added BAL from various samples of human urine. Curve $A$, male urine, 'dithiol blank' nil; curve $B$, female urine, 'dithiol blank' $3.6 \mu \mathrm{g} . / \mathrm{ml}$; curve $C$, male urine, 'dithiol blank' $3.2 \mu \mathrm{g} . / \mathrm{ml}$.; curve $D$, female urine, 'dithiol blank' 11.3 $\mu \mathrm{g} . / \mathrm{ml}$. (All 'dithiol blanks' calculated as BAL.)

Upon the recovery of added substances in biological fluids, a few general remarks are necessary. If the recovery of any substance is determined when added to biological media such as blood and urine, theoretical or lower than theoretical results are times proves the point and the second addition gives a $100 \%$ recovery. However, an experiment of this nature with BAL in urine gave $31 \%$ recovery for the first addition and $46 \%$ for the second. 
$\therefore$

\section{SUMMARY}

1. A new method for the determination of 1:2dithiols is described, depending on the fact that cyanogen chloride reacts with 1:2-dithiols to give a compound which readily liberates thiocyanate in alkaline solution.

2. 1:3-Dimercaptopropanol and the oxidized form of BAL do not react. Of many thiol compounds, only glutathione, ergothioneine and thiolacetic acid interfere.
3. A method for the determination of $B \dot{B A L}$ in blood is described, but a satisfactory method in the case of urine has not been found. The results obtained are discussed.

4. The mechanism of the reaction is discussed.

I wish to thank the Chief Scientist of the Ministry of Supply for permission to publish this work and Dr L. A. Stocken (Department of Biochemistry, Oxford) for many of the samples of thio compounds. I am also indebted to Mrs L. Currell and Miss A. E. Scott for their painstaking technical assistance; without their keenness this work would scarcely have been possible.

\title{
REFERENCES
}

Aldridge, W. N. (1944). Analyst, 69, 262.

Aldridge, W. N. (1945). Analyst, 70, 474.

Aldridge, W. N. \& Evans C. Lovatt (1946). Quart. J. exp.

Physiol. 33, 241.

Folin, O. (1930). J. biol. Chem. 86, 173.
Spray, G. H. (1944). Report to Ministry of Supply by Peters, no. 79.*

Spray, G. H., Stocken, L. A. \& Thompson, R. H. S. (1945). Report to Ministry of Supply by Peters, no. 85.*

* Information available on application to Ministry of Supply, London.

\section{The Estimation of Urethane (Ethyl Carbamate) in Blood}

\author{
By H. E. ARCHER, L. CHAPMAN, EVA RHODEN AND F. L. WARREN \\ The Chester Beatty Research Institute, The Royal Cancer Hospital (Free), Fulham Road, London, S.W. 3 \\ and The Pathological Department, Wellhouse Hospital, Barnet
}

(Received 22 April 1947)

In connexion with the recent use of urethane in the treatment of leukaemia (Haddow \& Sexton, 1946; Paterson, Ap Thomas, Haddow \& Watkinson, 1946), the necessity arose for a method for estimating this substance in blood.

The very simplicity of the chemical structure, $\mathrm{NH}_{2} \cdot \mathrm{COOC}_{2} \mathrm{H}_{5}$, and its close resemblance to urea, indicated that attempts to estimate urethane by reactions based on the amino group were unlikely to be successful. Attention was therefore directed to the characteristic ester grouping. It was found that urethane is quantitatively hydrolyzed to ethanol, ammonia, and carbonate, by boiling with sodium hydroxide solution. The ethanol can be estimated by distillation into acid potassium dichromate solution followed by titration of excess dichromate with sodium thiosulphate after addition of potassium iodide.

\section{METHOD}

The estimation involves two stages:

(1) Determination of volatile reducing substances in blood before alkaline hydrolysis. Folin-Wu blood filtrate $(10 \mathrm{ml}$.) is measured into a $100 \mathrm{ml}$. flask containing a few glass beads and connected with a Jackison's condenser which has its delivery tube extended downwards for about $15 \mathrm{~cm}$. The delivery tube dips below the surface of a mixture of potassium dichromate and sulphuric acid $(1 \mathrm{ml}$. of $0.1 \mathrm{~N}$ $\mathrm{K}_{2} \mathrm{Cr}_{2} \mathrm{O}_{7}$ and $5 \mathrm{ml}$. A.R. conc. $\mathrm{H}_{2} \mathrm{SO}_{4}$ ) which is contained in a tube of $20 \mathrm{ml}$. capacity. The tube containing the mixture is well cooled in ice. With no water cooling on the condenser, about $8 \mathrm{ml}$. of the flask's contents is distilled over into the oxidizing mixture. A glass stopper is sealed into the tube with a drop of conc. $\mathrm{H}_{2} \mathrm{SO}_{4}$ and the contents mixed and heated to $80^{\circ}$ for $20 \mathrm{~min}$. The tube is then cooled and the contents washed into a flask with about $100 \mathrm{ml}$. of water, $5 \mathrm{ml}$. of $5 \% \mathrm{KI}$ solution are added and the liberated iodine titrated with $0 \cdot 1 \mathrm{~N}$-sodium thiosulphate.

The above determination usually yields a small blank value.

(2) Determination of volatile reducing substances in blood after alkaline hydrolysis. A clean flask is fitted to the condenser, and a mixture of $10 \mathrm{ml}$. of blood filtrate together with $5 \mathrm{ml}$. of $10 \mathrm{~N}-\mathrm{NaOH}$ is refluxed for $15 \mathrm{~min}$. The water supply to the condenser is then stopped and 8-10 ml. of the flask's contents distilled into acid dichromate mixture as in (1). The subsequent procedure is as described in (1) above.

The difference between the dichromate reduced in (1) and in (2) is a measure of the urethane content of the blood. $1 \mathrm{ml}$. of $0.1 \mathrm{~N}$-dichromate is equivalent to $2.225 \mathrm{mg}$. of urethane. 